\title{
Pengaruh Kualitas Pelayanan Terhadap Tingkat Kepuasan Pasien BPJS Di Pelayanan Rawat Jalan RSUD Ratu Zalecha Martapura Tahun 2019
}

\author{
Noorhidayah, Septi Anggraeni, Siti Fatimah Tuzzahra \\ Fakultas Kesehatan Masyarakat \\ Universitas Islam Kalimantan (UNISKA) Muhammad Arsyad Al Banjary Banjarmasin \\ dayah_ibnu92@yahoo.co.id
}

DOI: https://doi.org/10.33859/dksm.v10i2.525

\begin{abstract}
Abstrak
Latar Belakang : Kualitas pelayanan sangat mempengaruhi kepuasan pasien, salah satu alat indikator yang di jadikan ukuran keberhasilan pelaksanaan JKN adalah indeks kepuasan masyarakat/ pasien (Wijono, 2009). Berdasarkan kritik dan saran tahun 2018 melalui kotak surat di RSUD Ratu Zalecha menyatakan ketidakpuasan pasien terhadap pelayanan yang diberikan oleh petugas kesehatan.

Tujuan Penelitian : mengetahui pengaruh kualitas pelayanan BPJS terhadap kepuasan pasien BPJS di Pelayanan Rawat Jalan Rumah Sakit Umum Ratu Zalecha Tahun 2019

Metode Penelitian : penelitian survei analitik dengan pendekatan cross sectional dengan total sampling yaitu sebanyak 100 orang.

Hasil : Hasil uji statistik dengan menggunakan analisis simple linear regression didapatkan hasil dimensi bukti nyata, kehandalan, ketanggapan, jaminan, dimensi empati berpengaruh terhadap kepuasan pasien BPJS di Pelayanan Rawat Jalan Rumah Sakit Umum Ratu Zalecha Tahun 2019

Kesimpulan : ada pengaruh signifikan bukti nyata (tangible), kehandalan (reliability), ketanggapan (responsiveness), jaminan (assurance), empati (empaty) terhadap kepuasan pasien BPJS di Pelayanan Rawat Jalan Rumah Sakit Umum Ratu Zalecha Tahun 2019. Diharapkan pelayanan rawat jalan Rumah Sakit Umum Ratu Zalecha dapat meningkatkan lagi kualitas pelayanan, pegawai/ karyawan tepat waktu dalam memberikan pelayanan dengan kualitas pelayanan yang memuaskan terutama dalam hal ketanggapan (responsiveness) dan kehandalan (reliability), penelitian survei analitik dengan pendekatan cross sectional dengan total sampling yaitu sebanyak 100 orang. serta meningkatkan sistem informasi manajemen Rumah Sakit untuk lebih memudahkan pelayanan.
\end{abstract}

Kata kunci: Kualitas Pelayanan, Kepuasan, Pelayanan BPJS, Pasien Rawat Jalan 


\begin{abstract}
Background : Quality of service greatly affects patient satisfaction, one of the indicators used as a measure of the success of JKN implementation is the community / patient satisfaction index (Wijono, 2009). Based on criticisms and suggestions in 2018 through a mailbox at Ratu Zalecha Regional Hospital expressed patient dissatisfaction with the services provided by health workers.

purposes : find out the influence of BPJS service quality on BPJS patient satisfaction in the Outpatient Services of Ratu Zalecha General Hospital in 2019.

methods: analytic survey research with cross sectional approach with a total sampling of 100 people. Results: Statistical test results using simple linear regression analysis showed the results of the dimensions of real evidence, reliability, responsiveness, assurance, empathy dimensions affect the satisfaction of BPJS patients in the Outpatient Services of Ratu Zalecha General Hospital in 2019 Conclusion: there is a significant effect of tangible evidence, reliability, responsiveness, assurance, empathy for the satisfaction of BPJS patients in the outpatient services at Ratu Zalecha General Hospital in 2019. It is expected that the outpatient services of the hospital General Ratu Zalecha can improve the quality of services, employees / employees on time in providing services with satisfactory service quality, especially in terms of responsiveness and reliability, analytical survey research with cross sectional approach with a total sampling of 100 people. and improve hospital management information systems to make services easier.
\end{abstract}

Keywords: Service Quality, Satisfaction, BPJS Services, Outpatients

\section{PENDAHULUAN}

Pemerintah telah menjamin setiap warga negara untuk mendapatkan jaminan kesehatan melalui program jaminan kesehatan nasional (JKN). Salah satu alat indikator yang di jadikan ukuran keberhasilan pelaksanaan JKN adalah indeks kepuasan masyarakat/ pasien (Wijono, 2009). Meningkatnya kesadaran masyarakat akan kesehatan, akan mengakibatkan tuntutan peningkatan pelayanan kesehatan. Semakin meningkatnya tuntutan masyarakat akan kualitas pelayanan kesehatan, maka fungsi pelayanan secara keseluruhan perlu ditingkatkan untuk memberi kepuasan pasien. Permasalahan yang sering terjadi di Rumah Sakit adalah ketersediaan tenaga kesehatan yang kurang serta kelengkapan obat yang belum memadai, ditambah dengan sikap dan perilaku petugas kesehatan dengan pasien, hal tersebut banyak mempengaruhi minat masyarakat khususnya pasien BPJS kesehatan di Rumah Sakit (Alamsyah, 2011).

Berdasarkan pengumpulan data elektronik rekam medik di Rumah Sakit Ratu 
Dinamika Kesehatan Jurnal Kebidanan dan Keperawatan Vol 10 No. 22019 ( ISSN: 2086-3454 EISSN: 2549-4058)

url: http://ojs.dinamikakesehatan.unism.ac.id DOI: https://doi.org/10.33859/dksm.v10i2

Pengaruh Kualitas Pelayanan Terhadap Tingkat Kepuasan Pasien BPJS Di Pelayanan Rawat Jalan RSUD Ratu Zalecha Martapura Tahun 2019

Zalecha Martapura didapatkan kunjungan rawat jalan peserta BPJS pada bulan Januari sampai Maret 2019 sebanyak 12.933 kunjungan. Berdasarkan wawancara dengan kepala bidang pelayanan rawat jalan RSUD Ratu Zalecha didapatkan selama tahun 2018 terdapat 2 kritik dan saran yang diberikan oleh pasien melalui kotak surat yang menyatakan ketidakpuasan pasien terhadap pelayanan yang diberikan oleh petugas kesehatan. Hasil studi pendahuluan melalui wawancara kepada 6 (enam) pasien BPJS rawat jalan RSUD Ratu Zalecha menyatakan ketidakpuasan pasien meliputi dimensi bukti nyata, dimensi ketanggapan, kehandalan dalam pelayanan, dimensi jaminan, serta empaty. Berdasarkan data dan fenomena yang ada maka peneliti tertarik untuk mengambil judul "Pengaruh kualitas pelayanan BPJS terhadap kepuasan pasien BPJS di Pelayanan Rawat Jalan Rumah Sakit Umum Ratu Zalecha Tahun 2019.

\section{BAHAN DAN METODE}

Penelitian ini menggunakan metode survei analitik dengan pendekatan cross sectional. Pengambilan sampel menggunakan teknik accidental sampling dengan besar sampel sebanyak 100 orang. Populasi dalam penelitian ini adalah semua pasien BPJS rawat jalan pada bulan Januari sampai Maret 2019 sebanyak 12.933 kunjungan. Hasil uji statistik dengan analisis regresi linear sederhana atau simple linear regression.

\section{HASIL DAN PEMBAHASAN}

\section{Hasil Univariat}

Gambaran kepuasan pasien BPJS di Pelayanan Rawat Jalan Rumah Sakit Umum Ratu Zalecha Tahun 2019.

Berdasarkan data yang didapatkan melalui kuesioner tentang kepuasan pasien BPJS di Pelayanan Rawat Jalan Rumah Sakit Umum Ratu Zalecha dapat dilihat pada tabel 1 dibawah ini :

Tabel 1 : Distribusi Frekuensi kepuasan pasien BPJS di Pelayanan Rawat Jalan Rumah Sakit Umum Ratu Zalecha Tahun 2019

\begin{tabular}{|c|c|c|c|}
\hline No & Kepuasan & $\begin{array}{c}\text { Frekuensi } \\
(\mathbf{n})\end{array}$ & $\begin{array}{c}\text { Persentase } \\
(\mathbf{\%})\end{array}$ \\
\hline 1. & Tidak Puas & 19 & 19 \\
\hline 2. & Puas & 81 & 81 \\
\hline Jumlah & & $\mathbf{1 0 0}$ & $\mathbf{1 0 0}$ \\
\hline
\end{tabular}

Tabel 1 menunjukkan bahwa kepuasan pasien BPJS di Pelayanan Rawat Jalan Rumah Sakit Umum Ratu Zalecha terbanyak pada kategori puas dengan jumlah 81 orang (81\%). 


\section{Bukti nyata (Tangible)}

Berdasarkan data yang didapatkan, bukti nyata (Tangible) di Pelayanan Rawat Jalan Rumah Sakit Umum Ratu Zalecha Tahun

2019 dapat dilihat pada tabel 2 dibawah ini :

Tabel 2. Distribusi Frekuensi Responden bukti nyata (Tangible) di Pelayanan Rawat Jalan Rumah Sakit Umum Ratu Zalecha Tahun 2019

\begin{tabular}{cccc}
\hline No. & $\begin{array}{c}\text { Bukti nyata } \\
\text { (Tangible) }\end{array}$ & $\begin{array}{c}\text { Frekuensi } \\
\text { (n) }\end{array}$ & $\begin{array}{c}\text { Persentase } \\
(\%)\end{array}$ \\
\hline 1. & Tidak Baik & 15 & 15 \\
\hline 2. & Baik & 85 & 85 \\
\hline Jumlah & & $\mathbf{1 0 0}$ & $\mathbf{1 0 0}$ \\
\hline
\end{tabular}

Tabel 2 menunjukkan bahwa bukti nyata

(Tangible) di Pelayanan Rawat Jalan Rumah

Sakit Umum Ratu Zalecha terbanyak pada

kategori baik dengan jumlah 85 orang $(85 \%)$.

\section{Kehandalan (Reliability)}

Berdasarkan data yang didapatkan, kehandalan (Reliability) Pelayanan Rawat

Jalan Rumah Sakit Umum Ratu Zalecha Tahun

2019 dapat dilihat pada tabel 3 dibawah ini :

Tabel 3 : Distribusi Frekuensi kehandalan (Reliability) di Pelayanan Rawat Jalan Rumah Sakit Umum Ratu Zalecha Tahun 2019

\begin{tabular}{cccc}
\hline No & $\begin{array}{c}\text { Kehandalan } \\
\text { (Reliability) }\end{array}$ & $\begin{array}{c}\text { Frekuensi } \\
(\mathbf{n})\end{array}$ & $\begin{array}{c}\text { Persentase } \\
(\mathbf{\%})\end{array}$ \\
\hline 1. & Tidak Baik & 18 & 18 \\
\hline 2. & Baik & 82 & 82 \\
\hline Jumlah & & $\mathbf{1 0 0}$ & $\mathbf{1 0 0}$ \\
\hline
\end{tabular}

Tabel 3 menunjukkan bahwa kehandalan (Reliability) terbanyak pada kategori baik dengan jumlah 82 orang ( $82 \%)$

\section{Ketanggapan (responsiveness)}

Berdasarkan data yang didapatkan, ketanggapan (responsiveeness) di Pelayanan Rawat Jalan Rumah Sakit Umum Ratu Zalecha Tahun 2019 dapat dilihat pada tabel 4 dibawah:

Tabel 4 : Distribusi Frekuensi Responden Berdasarkan ketanggapan (responsiveeness) di Pelayanan Rawat Jalan Rumah Sakit Umum Ratu Zalecha Tahun 2019

\begin{tabular}{cccc}
\hline No & $\begin{array}{c}\text { Ketanggapan } \\
\text { (responsiveness) }\end{array}$ & $\begin{array}{c}\text { Frekuensi } \\
\text { (n) }\end{array}$ & $\begin{array}{c}\text { Persentase } \\
\mathbf{( \% )}\end{array}$ \\
\hline 1. & Tidak Baik & 22 & 22
\end{tabular}

\begin{tabular}{lccc}
\hline 2. & Baik & 78 & 43,1 \\
\hline Jumlah & & $\mathbf{1 0 0}$ & $\mathbf{1 0 0}$ \\
\hline
\end{tabular}

Tabel 4 menunjukkan bahwa ketanggapan (responsiveeness) terbanyak pada kategori baik dengan jumlah 78 orang (78\%).

\section{Jaminan (assurance)}

Berdasarkan data yang didapatkan, Jaminan (assurance) di Pelayanan Rawat Jalan Rumah Sakit Umum Ratu Zalecha Tahun 2019 dapat dilihat pada tabel 5 dibawah ini :

Tabel 5 : Distribusi Frekuensi Responden Berdasarkan Jaminan (assurance) di Pelayanan Rawat Jalan Rumah Sakit Umum Ratu Zalecha Tahun 2019

\begin{tabular}{cccc}
\hline No. & $\begin{array}{c}\text { Jaminan } \\
\text { (assurance) }\end{array}$ & $\begin{array}{c}\text { Frekuensi } \\
\text { (n) }\end{array}$ & $\begin{array}{c}\text { Persentase } \\
(\mathbf{\%})\end{array}$ \\
\hline 1. & Tidak Baik & 20 & 20 \\
\hline 2. & Baik & 80 & 80 \\
\hline Jumlah & & $\mathbf{1 0 0}$ & $\mathbf{1 0 0}$ \\
\hline
\end{tabular}


Dinamika Kesehatan Jurnal Kebidanan dan Keperawatan Vol 10 No. 22019 ( ISSN: 2086-3454 EISSN: 2549-4058)

url: http://ojs.dinamikakesehatan.unism.ac.id DOI: https://doi.org/10.33859/dksm.v10i2

Pengaruh Kualitas Pelayanan Terhadap Tingkat Kepuasan Pasien BPJS Di Pelayanan Rawat Jalan RSUD Ratu Zalecha Martapura Tahun 2019

Tabel 5 menunjukkan bahwa jaminan (assurance) terbanyak pada kategori baik dengan jumlah 80 orang $(80 \%)$.

Empati (empaty) Berdasarkan data yang didapatkan, empati (empaty) di Pelayanan Rawat Jalan Rumah Sakit Umum Ratu Zalecha Tahun 2019 dapat dilihat pada tabel 6 dibawah:

Tabel 6 : Distribusi Frekuensi Responden Berdasarkan dimensi empati (empaty) di Pelayanan Rawat Jalan Rumah Sakit Umum Ratu Zalecha Tahun 2019

\begin{tabular}{cccc}
\hline No. & $\begin{array}{c}\text { Empati } \\
\text { (empaty) }\end{array}$ & $\begin{array}{c}\text { Frekuensi } \\
\text { (n) }\end{array}$ & $\begin{array}{c}\text { Persentase } \\
(\%)\end{array}$ \\
\hline 1. & Tidak Baik & 21 & 21 \\
\hline 2. & Baik & 79 & 79 \\
\hline Jumlah & & $\mathbf{1 0 0}$ & $\mathbf{1 0 0}$ \\
\hline
\end{tabular}

Tabel 6 menunjukkan bahwa empati (empaty) terbanyak pada kategori baik dengan jumlah 79 orang $(79 \%)$.

\section{Hasil Bivariat}

Analisis Bivariat mengukur besarnya pengaruh kualitas pelayanan BPJS terhadap kepuasan pasien BPJS di Pelayanan Rawat Jalan Rumah Sakit Umum Ratu Zalecha Tahun 2019.

Pada penelitian ini Analisis bivariat digunakan untuk mencari pengaruh bukti nyata (tangible) terhadap kepuasan pasien BPJS di Pelayanan Rawat Jalan Rumah Sakit Umum Ratu Zalecha Tahun 2019
Tabel 7 Pengaruh bukti nyata (tangible) terhadap kepuasan pasien BPJS diPelayanan Rawat Jalan Rumah Sakit Umum Ratu Zalecha Tahun 2019

\begin{tabular}{cccccccc}
\hline No & \multirow{3}{*}{$\begin{array}{c}\text { Bukti Nyata } \\
\text { (tangible) }\end{array}$} & \multicolumn{3}{c}{ Kepuasan pasien BPJS } & \multirow{2}{*}{ Total } \\
\cline { 3 - 6 } & & $\mathrm{n}$ & $\%$ & $\mathrm{n}$ & $\%$ & $\mathrm{n}$ & $\%$ \\
\cline { 3 - 6 } & Tidak Puas & \multicolumn{2}{c}{ Puas } & & \\
\hline 1 & Tidak Baik & 8 & 53,3 & 7 & 46,7 & 15 & 100 \\
\hline 2 & 11 & 12,9 & 74 & 87,1 & 85 & 100 \\
\hline & Total & 19 & 19,0 & 81 & 81,0 & 100 & 100 \\
\hline \multicolumn{6}{c}{$p$-value $=0,000<\alpha$} & 0,05 \\
\hline
\end{tabular}

Berdasarkan tabel 7 menunjukkan bahwa responden yang menyatakan bukti nyata (tangible) tidak baik lebih banyak merasa puas $(53,3 \%)$ dibandingkan dengan yang merasa puas $(46,7 \%)$, sedangkan pada responden yang menyatakan bukti nyata (tangible) baik lebih banyak menyatakan puas $(87,1 \%)$ dibandingkan dengan yang merasa tidak puas (12,9\%). Hasil uji statistik dengan analisis regresi linear sederhana atau simple linear regression di dapatkan nilai $p$-value $=0,000<$ $\alpha$ 0,05 yang artinya ada pengaruh signifikan bukti nyata (tangible) terhadap kepuasan pasien BPJS di Pelayanan Rawat Jalan Rumah Sakit umum Ratu Zalecha Tahun 2019 dengan nilai nilai $\mathrm{R}$ Square 0,135 artinya sebesar $13,5 \%$ bukti nyata (tangible) berpengaruh terhadap kepuasan pasien BPJS sedangkan 86,5\% kepuasan pasien BPJS di pengaruhi variabel yang lain. Dengan persamaan regresi 
Dinamika Kesehatan Jurnal Kebidanan dan Keperawatan Vol 10 No. 22019 ( ISSN: 2086-3454 EISSN: 2549-4058)

url: http://ojs.dinamikakesehatan.unism.ac.id DOI: https://doi.org/10.33859/dksm.v10i2

Pengaruh Kualitas Pelayanan Terhadap Tingkat Kepuasan Pasien BPJS Di Pelayanan Rawat Jalan RSUD Ratu Zalecha Martapura Tahun 2019

$y=1,063+0,404 x$ sehingga semakin baik bukti nyata (tangible) maka akan semakin tinggi tingkat kepuasan pasien BPJS di Pelayanan Rawat Jalan Rumah Sakit Umum Ratu Zalecha Tahun 2019.

Pengaruh kehandalan (reliability) terhadap kepuasan pasien BPJS di Pelayanan Rawat Jalan Rumah Sakit Umum Ratu Zalecha Tahun 2019.

Dari hasil analisis bivariat pengaruh kehandalan (reliability) terhadap kepuasan pasien BPJS di Pelayanan Rawat Jalan Rumah Sakit Umum Ratu Zalecha Tahun 2019 adalah sebagai berikut :

Tabel 8 Pengaruh kehandalan (reliability) terhadap kepuasan pasien BPJS di Pelayanan Rawat Jalan Rumah Sakit Umum Ratu Zalecha Tahun 2019

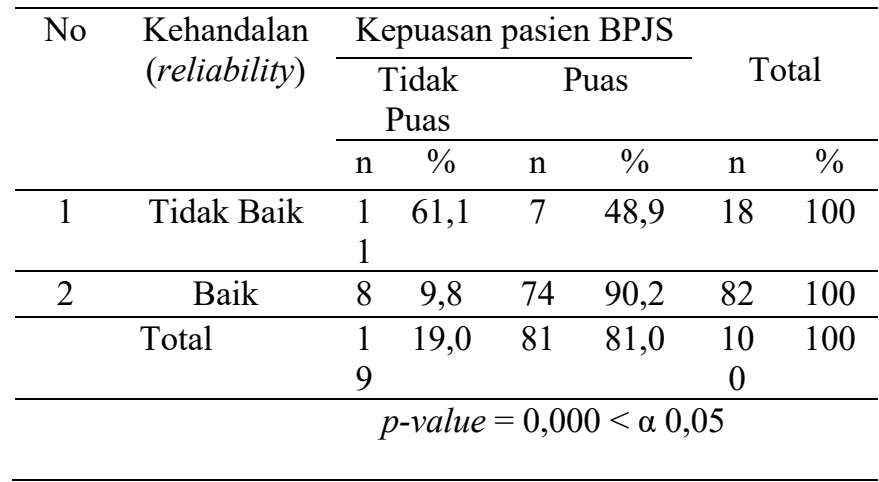

Berdasarkan tabel 8 menunjukkan bahwa responden yang menyatakan kehandalan (reliability) tidak baik lebih banyak merasa tidak puas $(61,1 \%)$ dibandingkan dengan yang merasa puas $68(48,9 \%)$, sedangkan pada

responden yang menyatakan kehandalan (reliability) baik lebih banyak menyatakan puas $(90,2 \%)$ dibandingkan dengan yang merasa tidak puas $(9,8 \%)$. Hasil uji statistik dengan analisis regresi linear sederhana atau simple linear regression di dapatkan nilai $p$-value $=$ $0,000<\alpha 0,05$ artinya ada pengaruh yang signifikan kehandalan (reliability) terhadap kepuasan pasien BPJS di Pelayanan Rawat Jalan Rumah Sakit Umum Ratu Zalecha Tahun 2019 dengan nilai R Square 0,253 artinya sebesar 25,3\% kehandalan (reliability) berpengaruh terhadap kepuasan pasien BPJS sedangkan 74,7\% kepuasan pasien BPJS di pengaruhi variabel yang lain. Dengan persamaan regresi $y=0,875+0,514 x$ sehingga disimpulkan semakin baik kehandalan (reliability) maka akan semakin tinggi tingkat kepuasan pasien BPJS di Pelayanan Rawat Jalan Rumah Sakit Umum Ratu Zalecha Tahun 2019.

Pengaruh ketanggapan (responsiveness) terhadap kepuasan pasien BPJS di Pelayanan Rawat Jalan Rumah Sakit Umum Ratu Zalecha Tahun 2019. 
Dinamika Kesehatan Jurnal Kebidanan dan Keperawatan Vol 10 No. 22019 ( ISSN: 2086-3454 EISSN: 2549-4058)

url: http://ojs.dinamikakesehatan.unism.ac.id DOI: https://doi.org/10.33859/dksm.v10i2

Pengaruh Kualitas Pelayanan Terhadap Tingkat Kepuasan Pasien BPJS Di Pelayanan Rawat Jalan RSUD Ratu Zalecha Martapura Tahun 2019

Dari hasil analisis bivariat pengaruh ketanggapan (responsiveness) terhadap kepuasan pasien BPJS di Pelayanan Rawat Jalan Rumah Sakit Umum Ratu Zalecha Tahun 2019 adalah sebagai berikut :

Tabel 9 Pengaruh ketanggapan (responsiveness) terhadap kepuasan pasien BPJS di Pelayanan Rawat Jalan Rumah Sakit Umum Ratu Zalecha Tahun 2019

\begin{tabular}{|c|c|c|c|c|c|c|c|}
\hline \multirow[t]{4}{*}{ No } & & \multicolumn{4}{|c|}{ Kepuasan pasien } & \multirow{3}{*}{\multicolumn{2}{|c|}{ Total }} \\
\hline & \multirow{3}{*}{$\begin{array}{c}\text { ketanggapan } \\
\text { (responsiven } \\
\text { ess) }\end{array}$} & \multicolumn{4}{|c|}{ BPJS } & & \\
\hline & & \multicolumn{2}{|c|}{$\begin{array}{l}\text { Tidak } \\
\text { Puasan }\end{array}$} & \multicolumn{2}{|c|}{ Puas } & & \\
\hline & & $\mathrm{n}$ & $\%$ & $\mathrm{n}$ & $\%$ & $\mathrm{n}$ & $\%$ \\
\hline \multirow[t]{2}{*}{1} & Tidak Baik & 1 & 54,5 & 1 & 45,5 & 22 & 100 \\
\hline & & 2 & & 0 & & & \\
\hline \multirow[t]{4}{*}{2} & Baik & 7 & 9,0 & 7 & 91,0 & 78 & 100 \\
\hline & & & & 4 & & & \\
\hline & Total & 1 & 19,0 & 8 & 81,0 & 10 & 100 \\
\hline & & 9 & & 1 & & 0 & \\
\hline
\end{tabular}

Berdasarkan tabel 9 menunjukkan bahwa responden yang menyatakan ketanggapan (responsiveness) tidak baik lebih banyak merasa tidak puas $(54,5 \%)$ dibandingkan dengan yang merasa puas $(45,5 \%)$ sedangkan pada responden yang menyatakan ketanggapan (responsiveness) baik lebih banyak menyatakan puas $(91,0 \%)$ dibandingkan dengan yang merasa tidak puas $(9,0 \%)$. Hasil uji statistik dengan analisis regresi linear sederhana atau simple linear regression di dapatkan nilai $p$ value $=0,000<\alpha 0,05$ artinya ada pengaruh yang signifikan ketanggapan (responsiveness) terhadap kepuasan pasien BPJS di Pelayanan Rawat Jalan Rumah Sakit Umum Ratu Zalecha Tahun 2019 dengan nilai $\mathrm{R}$ Square 0,232 artinya sebesar $23,2 \%$. Ketanggapan (responsiveness) berpengaruh terhadap kepuasan pasien BPJS sedangkan 76,8\% kepuasan pasien BPJS di pengaruhi variabel yang lain. Dengan persamaan regresi $y=0,999+0,456 x \quad 70$ sehingga disimpulkan semakin baik ketanggapan (responsiveness) maka akan semakin tinggi tingkat kepuasan pasien BPJS di Pelayanan Rawat Jalan Rumah Sakit Umum Ratu Zalecha Tahun 2019.

Analisis bivariat digunakan untuk mencari pengaruh jaminan (assurance) terhadap kepuasan pasien BPJS di Pelayanan Rawat Jalan Rumah Sakit Umum Ratu Zalecha Tahun 2019

Tabel 10 Pengaruh jaminan (assurance) terhadap kepuasan pasien BPJS di Pelayanan Rawat Jalan Rumah Sakit Umum Ratu Zalecha Tahun 2019

\begin{tabular}{|c|c|c|c|c|c|c|c|}
\hline \multirow[t]{3}{*}{ No } & \multirow{3}{*}{$\begin{array}{c}\text { Jaminan } \\
\text { (assuran } \\
\text { ce) }\end{array}$} & \multicolumn{4}{|c|}{ Kepuasan pasien BPJS } & \multirow{2}{*}{\multicolumn{2}{|c|}{ Total }} \\
\hline & & \multicolumn{2}{|c|}{$\begin{array}{l}\text { Tidak } \\
\text { Puas }\end{array}$} & \multicolumn{2}{|c|}{ Puas } & & \\
\hline & & $\mathrm{n}$ & $\%$ & $\mathrm{n}$ & $\%$ & $\mathrm{n}$ & $\%$ \\
\hline 1 & $\begin{array}{l}\text { Tidak } \\
\text { Baik }\end{array}$ & 11 & 55,0 & 9 & 45,0 & 20 & 100 \\
\hline 2 & Baik & 8 & 10,0 & 72 & 90,0 & 80 & 100 \\
\hline & Total & 19 & 19,0 & 81 & 81,0 & $\begin{array}{c}10 \\
0\end{array}$ & 100 \\
\hline & & & -valu & 0 & $<0$ & & \\
\hline
\end{tabular}


Dinamika Kesehatan Jurnal Kebidanan dan Keperawatan Vol 10 No. 22019 ( ISSN: 2086-3454 EISSN: 2549-4058)

url: http://ojs.dinamikakesehatan.unism.ac.id DOI: https://doi.org/10.33859/dksm.v10i2

Pengaruh Kualitas Pelayanan Terhadap Tingkat Kepuasan Pasien BPJS Di Pelayanan Rawat Jalan RSUD Ratu Zalecha Martapura Tahun 2019

Berdasarkan tabel 10 didapatkan responden yang menyatakan jaminan (assurance) tidak baik lebih banyak merasa tidak puas $(55,0 \%)$ dibandingkan dengan yang merasa puas $(45,0 \%)$, sedangkan pada responden yang menyatakan jaminan (assurance) baik lebih banyak menyatakan puas $(90,0 \%)$ dibandingkan dengan yang merasa tidak puas (10,0\%). Hasil uji statistik dengan analisis regresi linear sederhana atau simple linear regression di dapatkan nilai $p$-value $=0,000<$ $\alpha 0,05$ artinya ada pengaruh yang signifikan jaminan (assurance) terhadap kepuasan pasien BPJS di Pelayanan Rawat Jalan Rumah Sakit Umum Ratu Zalecha Tahun 2019 dengan nilai R Square 0,211 artinya sebesar 21,1\% jaminan (assurance) berpengaruh terhadap kepuasan pasien BPJS sedangkan 78,9\% kepuasan pasien BPJS di pengaruhi variabel yang lain. Dengan persamaan regresi $\mathrm{y}=1,000+0,450 \mathrm{x}$ sehingga disimpulkan semakin baik jaminan (assurance) maka akan semakin tinggi tingkat kepuasan pasien BPJS di Pelayanan Rawat Jalan Rumah Sakit Umum Ratu Zalecha Tahun 2019.
Pengaruh empati (empaty) terhadap kepuasan pasien BPJS di Pelayanan Rawat Jalan Rumah Sakit Umum Ratu Zalecha Tahun 2019.

Tabel 11 Pengaruh empati (empaty) terhadap kepuasan pasien BPJS di Pelayanan Rawat Jalan Rumah Sakit Umum Ratu Zalecha Tahun 2019

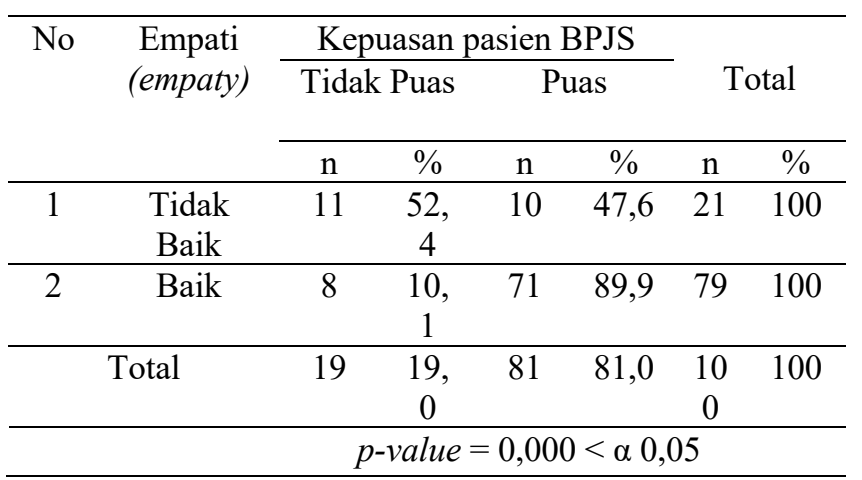

Berdasarkan tabel 11 menunjukkan bahwa responden yang menyatakan empati (empaty) tidak baik lebih banyak merasa tidak puas (52,4\%) dibandingkan dengan yang merasa puas $(47,6 \%)$, sedangkan pada responden yang menyatakan empati (empaty) baik lebih banyak menyatakan puas $(89,9 \%)$ dibandingkan dengan yang merasa tidak puas (10,1\%). Hasil uji statistik dengan analisis regresi linear sederhana atau simple linear regression di dapatkan nilai $p$-value $=0,000<\alpha 0,05$ artinya ada pengaruh yang signifikan empati (empaty) terhadap kepuasan pasien BPJS di Pelayanan Rawat Jalan Rumah Sakit Umum Ratu Zalecha Tahun 2019 dengan nilai $\mathrm{R}$ Square 0,192 
Dinamika Kesehatan Jurnal Kebidanan dan Keperawatan Vol 10 No. 22019 ( ISSN: 2086-3454 EISSN: 2549-4058)

url: http://ojs.dinamikakesehatan.unism.ac.id DOI: https://doi.org/10.33859/dksm.v10i2

Pengaruh Kualitas Pelayanan Terhadap Tingkat Kepuasan Pasien BPJS Di Pelayanan Rawat Jalan RSUD Ratu Zalecha Martapura Tahun 2019

(19,2\%) artinya sebesar 19,2\% empati (empaty)

berpengaruh terhadap kepuasan pasien BPJS sedangkan 80,8\% kepuasan pasien BPJS di pengaruhi variabel yang lain. Dengan persamaan regresi $\mathrm{y}=1,054+0,423 \mathrm{x}$ sehingga disimpulkan semakin baik empati (empaty) maka akan semakin tinggi tingkat kepuasan 73 pasien BPJS di Pelayanan Rawat Jalan Rumah Sakit Umum Ratu Zalecha Tahun 2019 .

\section{PEMBAHASAN}

Pengaruh Kualitas Pelayanan Terhadap Tingkat Kepuasan Pasien BPJS di Pelayanan Rawat Jalan RSUD Ratu Zalecha Martapura Tahun 2019 kepada 100 responden menggunakan kuesioner.

\section{Hasil Univariat}

\section{Kepuasan pasien BPJS}

Sebagian besar Kepuasan pasien BPJS merasa puas terhadap pelayanan rawat jalan yaitu 81 orang $(81,0 \%)$ menyatakan puas terhadap pelayanan kesehatan di rawat jalan, respon kecepatan daya tanggap petugas dalam menangani masalah kesehatan, keterampilan petugas pelayanan pengobatan, kebersihan dan kerapian pakaian yang digunakan petugas serta perhatian petugas selama menjalani pengobatan kesehatan. Responden yang merasa tidak puas terhadap pelayanan rawat jalan yang diberikan sebanyak 14 orang $(14,0 \%)$, tidak puas terhadap respon kecepatan daya tanggap petugas dalam menangani masalah kesehatan serta keterampilan petugas pelayanan pengobatan.

Responden yang tidak puas akan pelayanan rawat jalan di RSUD Ratu Zalecha disebabkan karena membandingkan antara harapan pasien dengan pelayanan yang diterimanya terhadap pelayanan yang didapatkan.

Kualitas Pelayanan BPJS berdasarkan dimensi bukti nyata (Tangible), kehandalan (Reliability), ketanggapan (Responsiveness), jaminan (Assurance) dan empati (Empaty) di Pelayanan Rawat Jalan Rumah Sakit Umum Ratu Zalecha Tahun 2019

Hasil penelitian menunjukkan sebagian besar menyatakan bukti nyata (tangible) baik sebanyak 86 orang $(86,0 \%)$ menyatakan bahwa ruangan perawatan bersih, rapi, nyaman dan tenang, penampilan petugas rapi. Responden yang menyatakan bukti nyata (tangible) tidak 
Dinamika Kesehatan Jurnal Kebidanan dan Keperawatan Vol 10 No. 22019 ( ISSN: 2086-3454 EISSN: 2549-4058)

url: http://ojs.dinamikakesehatan.unism.ac.id DOI: https://doi.org/10.33859/dksm.v10i2

Pengaruh Kualitas Pelayanan Terhadap Tingkat Kepuasan Pasien BPJS Di Pelayanan Rawat Jalan RSUD Ratu Zalecha Martapura Tahun 2019

baik sebanyak 13 orang $(13,0 \%)$ dalam hal kerapian ruang pemeriksaan, bangunan rumah sakit, lokasi dan tempat parkir.

Hasil penelitian dimensi kehandalan (reliability) menunjukkan sebagian besar menyatakan kehandalan (reliability) baik sebanyak 87 orang $(87,0 \%)$ petugas registrasi BPJS melayani dengan teliti dan baik, dokter yang memeriksa dengan teliti, perawat yang mempunyai kemampuan dalam melayani dengan hati-hati dan teliti. Sedangkan responden yang menyatakan kehandalan (reliability) tidak baik sebanyak 22 orang $(22,0 \%)$ dalam hal kehadiran/waktu dokter untuk memeriksa setiap hari serta kemampuan petugas apotik depo BPJS dalam menjelaskan obat.

Hasil penelitian dimensi ketanggapan (responsiveness) menunjukkan bahwa sebagian besar menyatakan baik sebanyak 84 orang $(84,0 \%)$ dalam hal ketanggapan petugas kesehatan memberikan pelayanan, pelayanan perawat dalam membantu keperluan pasien serta kecepatan petugas memberikan arahan saat pasien memerlukan informasi.
Responden yang menyatakan ketanggapan (responsiveness) tidak baik sebanyak 22 orang $(22,0 \%)$

dalam hal kesigapan dan kecepatan petugas dalam pelayanan registrasi di BPJS serta arahan dalam memberikan informasi kepada pasien.

Berdasarkan hasil kuesioner sebagian besar menyatakan jaminan (assurance) baik sebanyak 83 orang $(83,0 \%)$ pasien merasa terjamin keamanannya, dokter baik dan sopan dalam melakukan pemeriksaan, kejelasan pemberian informasi yang mudah dipahami. Masih ada responden yang menyatakan jaminan (assurance) tidak baik sebanyak 16 orang $(16,0 \%)$ menyatakan tidak baik dalam hal jaminan keamanan lingkungan tempat pelayanan.

Hasil penelitian menunjukkan bahwa sebagian besar menyatakan empati (empaty) baik sebanyak 83 orang $(83,0 \%)$ petugas registrasi BPJS baik dan ramah dalam memberikan pelayanan. dokter yang baik dalam memberikan penjelasan tentang penyakit yang diderita pasien, petugas yang menghargai 
Dinamika Kesehatan Jurnal Kebidanan dan Keperawatan Vol 10 No. 22019 ( ISSN: 2086-3454 EISSN: 2549-4058)

url: http://ojs.dinamikakesehatan.unism.ac.id DOI: https://doi.org/10.33859/dksm.v10i2

Pengaruh Kualitas Pelayanan Terhadap Tingkat Kepuasan Pasien BPJS Di Pelayanan Rawat Jalan RSUD Ratu Zalecha Martapura Tahun 2019

privasi pasien. Masih ada responden yang menyatakan empati (empaty) tidak baik sebanyak 35 orang $(35,0 \%)$, bahwa pelayanan rumah sakit masih membeda-bedakan antar pasien. perawat yang tidak baik dalam melayani dan memperhatikan kebutuhan pasien.

Kualitas pelayanan memiliki beberapa dimensi atau unsur kualitas pelayanan yaitu Bukti fisik (tangible), kehandalan (Reliability), Ketanggapan (Responsiveness), jaminan (Assurance), Empati (Empaty). Kualitas pelayanan diartikan sebagai tingkat kepuasan konsumen/pasien yang diperoleh dari perbandingan atas jenis pelayanan yang nyata diterima dengan jenis pelayanan yang diharapkan. Jika pelayanan dapat melampaui harapan konsumen, maka jenis kualitas pelayanan ini dapat dikategorikan sebagai pelayanan yang sangat berkualitas atau sangat memuaskan. Sedangkan jenis kualitas pelayanan yang buruk adalah jenis pelayanan yang berada jauh di bawah standar atau tidak sesuai dengan ekspekstasi pelayanan yang diharapkan oleh konsumen.

\section{Hasil Bivariat}

Pengaruh bukti nyata (Tangible) terhadap kepuasan pasien BPJS di Pelayanan Rawat Jalan Rumah Sakit Umum Ratu Zalecha Tahun 2019.

Hasil uji statistik dengan analisis regresi linear sederhana atau simple linear regression di dapatkan nilai $p$-value $=0,000<\alpha 0,05$ artinya ada pengaruh signifikan bukti nyata (tangible) terhadap kepuasan pasien BPJS di Pelayanan Rawat Jalan Rumah Sakit Umum Ratu Zalecha Tahun 2019 dengan nilai nilai $R$ Square 0,135 artinya sebesar $13,5 \%$ bukti nyata (tangible) berpengaruh terhadap kepuasan pasien BPJS sedangkan $86,5 \%$ kepuasan pasien BPJS di pengaruhi variabel yang lain. Dari hasil penelitian diketahui bahwa pasien yang mengatakan (tangible) baik tetapi tidak merasa puas disebabkan oleh persepsi pasien yang merasa tidak baik terhadap kenyamanan ruang pelayanan, kebersihan toilet dan ketersediaan air di rumah sakit. Dengan persamaan regresi $y=1,063+0,404 x \quad$ sehingga disimpulkan semakin baik bukti nyata (tangible) maka akan semakin tinggi tingkat kepuasan pasien BPJS di 
Dinamika Kesehatan Jurnal Kebidanan dan Keperawatan Vol 10 No. 22019 ( ISSN: 2086-3454 EISSN: 2549-4058)

url: http://ojs.dinamikakesehatan.unism.ac.id DOI: https://doi.org/10.33859/dksm.v10i2

Pengaruh Kualitas Pelayanan Terhadap Tingkat Kepuasan Pasien BPJS Di Pelayanan Rawat Jalan RSUD Ratu Zalecha Martapura Tahun 2019

Pelayanan Rawat Jalan Rumah Sakit Umum

Ratu Zalecha Tahun 2019. Hubungan bukti

fisik atau bukti nyata (tangible) dengan kepuasan pasien adalah bukti fisik (tangible) mempunyai pengaruh positif dan signifikan dengan kepuasan pasien. Semakin baik persepsi pasien terhadap bukti fisik (tangible) maka kepuasan pasien akan semakin tinggi. Dan jika persepsi pasien terhadap bukti fisik (tangible) tidak baik, maka kepuasan pasien semakin rendah.

Bukti fisik (tangible) adalah keadaan yang ada berupa penampilan fisik dari pegawai, cara berpakaian atau menggunakan uniformnya, peralatan yang digunakan di dalam bertugas, bahan-bahan sarana pelayanan lainnya (Parasuraman, 2010).

Pengaruh kehandalan (Reliability) terhadap kepuasan pasien BPJS di Pelayanan Rawat Jalan Rumah Sakit Umum Ratu Zalecha Tahun 2019.

Hasil uji statistik dengan analisis regresi linear sederhana atau simple linear regression di dapatkan nilai $p$-value $=0,000<\alpha 0,05$ artinya ada pengaruh yang signifikan kehandalan (reliability) terhadap kepuasan pasien BPJS di Pelayanan Rawat Jalan Rumah Sakit Umum Ratu Zalecha Tahun 2019 dengan nilai $\mathrm{R}$ Square 0,253 artinya sebesar $25,3 \%$ kehandalan (reliability) berpengaruh terhadap kepuasan pasien BPJS sedangkan 74,7\% kepuasan pasien BPJS di pengaruhi variabel yang lain. Reliability oleh pasien dikatakan baik dan puas dengan kualitas pelayanan yang dirasakan tersebut karena pasien merasa bahwa kehandalan yang dimiliki petugas kesehatan di Rumah Sakit Ratu Zalecha sudah baik, pelayanan kepada pasien tepat waktu sesuai dengan yang dijanjikan. dan Berdasarkan hasil penelitian pasien yang mengatakan (reliability) baik tetapi tidak puas dikarenakan kurang puas dengan apa yang disampaikan petugas, Dari 5 (lima) dimensi kualitas pelayanan kehandalan (reliability) mempunyai pengaruh paling besar terhadap kepuasan pasien yaitu 25,3\%. Dengan persamaan regresi $\quad \mathrm{y}=0,875+0,514 \mathrm{x}$ disimpulkan semakin baik kehandalan (reliability) maka akan semakin tinggi tingkat kepuasan pasien BPJS di Pelayanan Rawat 
Dinamika Kesehatan Jurnal Kebidanan dan Keperawatan Vol 10 No. 22019 ( ISSN: 2086-3454 EISSN: 2549-4058)

url: http://ojs.dinamikakesehatan.unism.ac.id DOI: https://doi.org/10.33859/dksm.v10i2

Pengaruh Kualitas Pelayanan Terhadap Tingkat Kepuasan Pasien BPJS Di Pelayanan Rawat Jalan RSUD Ratu Zalecha Martapura Tahun 2019

Jalan Rumah Sakit Umum Ratu Zalecha Tahun 2019.

Pengaruhketanggapan (Responsiveness) terhadap kepuasan pasien BPJS di Pelayanan Rawat Jalan Rumah Sakit Umum Ratu Zalecha Tahun 2019. Hasil uji statistik di dapatkan nilai $p$-value $=0,000<\alpha 0,05$ artinya ada pengaruh yang signifikan ketanggapan (Responsiveness) terhadap kepuasan pasien BPJS di Pelayanan Rawat Jalan Rumah Sakit Umum Ratu Zalecha Tahun 2019 dengan nilai R Square 0,232 artinya $\quad$ sebesar $\quad 23,2 \% \quad$ ketanggapan (responsiveness) berpengaruh terhadap kepuasan pasien BPJS sedangkan 76,8\% kepuasan pasien BPJS di pengaruhi variabel yang lain. Pasien menyatakan petugas tanggap dengan pelayanan dan puas dengan kualitas pelayanan yang dirasakan karena pasien merasa bahwa ketanggapan yang dimiliki petugas kesehatan sudah tanggap dalam hal cara petugas menjawab saat melayani, memberikan informasi kepada pasien, serta menerima keluhan pasien. Berdasarkan hasil penelitian masih ada pasien yang mengatakan petugas tanggap tetapi pasien tidak puas dikarenakan petugas kurang tanggap dalam memberikan pelayanan terutama kecepatan waktu.

Dengan persamaan regresi $\mathrm{y}=0,999+0,456 \mathrm{x}$ disimpulkan semakin baik ketanggapan (responsiveness) maka akan semakin tinggi tingkat kepuasan pasien BPJS di Pelayanan Rawat Jalan Rumah Sakit Umum Ratu Zalecha Tahun 2019. Menurut Semiaji Santoso (2012) daya tanggap adalah kesedian untuk membantu pasien dan memberikan dengan segera dan tepat. Pengaruh jaminan (Assurance) terhadap kepuasan pasien BPJS di Pelayanan Rawat Jalan Rumah Sakit Umum Ratu Zalecha Tahun 2019

Berdasarkan hasil penelitian di dapatkan nilai $p$-value $=0,000<\alpha 0,05$ artinya ada pengaruh yang signifikan jaminan (Assurance) terhadap kepuasan pasien BPJS di Pelayanan Rawat Jalan Rumah Sakit Umum Ratu Zalecha Tahun 2019 dengan nilai R Square 0,211 artinya sebesar $21,1 \%$ jaminan (assurance) berpengaruh terhadap kepuasan pasien BPJS sedangkan 78,9\% kepuasan pasien BPJS di pengaruhi variabel yang lain. Jaminan oleh pasien dikatakan baik dan puas dengan 
Dinamika Kesehatan Jurnal Kebidanan dan Keperawatan Vol 10 No. 22019 ( ISSN: 2086-3454 EISSN: 2549-4058)

url: http://ojs.dinamikakesehatan.unism.ac.id DOI: https://doi.org/10.33859/dksm.v10i2

Pengaruh Kualitas Pelayanan Terhadap Tingkat Kepuasan Pasien BPJS Di Pelayanan Rawat Jalan RSUD Ratu Zalecha Martapura Tahun 2019

kualitas pelayanan yang dirasakan karena pasien merasa bahwa jaminan yang diberikan oleh petugas sudah baik dalam hal jaminan penjelasan tentang pemeriksaan/ pelayanan, mudah dipahami dan dimengerti. Masih ada responden yang menyatakan jaminan tidak baik dikarenakan masih kurang dalam hal jaminan lingkungan tempat pelayanan apabila ada hal yang tidak diinginkan terjadi. Dengan persamaan regresi $y=1,000+0,450 x$ disimpulkan semakin baik jaminan (Assurance) maka akan semakin tinggi tingkat kepuasan pasien BPJS di Pelayanan Rawat Jalan Rumah Sakit Umum Ratu Zalecha Tahun 2019. Menurut Semiaji Santoso (2012) jaminan (Assurance) mencakup sifat-sifat yang dapat dipercaya dan dimiliki para staf, dan bebas dari bahaya, risiko atau keragu-raguan seperti pengetahuan, kemampuan dan kesopanan dalam pelayanan oleh petugas berkaitan dengan kemampuan petugas untuk menanamkan kepercayaan kepada pasien, sikap sopan dan kemampuan dalam memberikan informasi kepada pasien.
Pengaruh empati (empaty) terhadap kepuasan pasien BPJS di Pelayanan Rawat Jalan Rumah Sakit Umum Ratu Zalecha Tahun 2019 . Hasil uji statistik dengan analisis regresi linear sederhana atau simple linear regression di dapatkan nilai $p$-value $=0,000<\alpha 0,05$ artinya ada pengaruh yang signifikan empati (empaty) terhadap kepuasan pasien BPJS di Pelayanan Rawat Jalan Rumah Sakit Umum Ratu Zalecha Tahun 2019 dengan nilai R Square $0,192(19,2 \%)$ artinya sebesar 19,2\% empati (empaty) berpengaruh terhadap kepuasan pasien BPJS sedangkan 80,8\% kepuasan pasien BPJS di pengaruhi variabel yang lain.

Empaty oleh pasien dikatakan baik dan puas dengan kualitas pelayanan yang dirasakan karena persepsi pasien yang merasa bahwa empati yang dimiliki petugas sudah baik dalam hal registrasi BPJS, cara perawat melayani dan memperhatikan kebutuhan pasien, cara dokter memberikan penjelasan tentang penyakit yang diderita pasien dan petugas mengharagi privasi pasien. Sedangkan ada pasien yang mengatakan empati baik tetapi tidak merasa puas karena 
Dinamika Kesehatan Jurnal Kebidanan dan Keperawatan Vol 10 No. 22019 ( ISSN: 2086-3454 EISSN: 2549-4058)

url: http://ojs.dinamikakesehatan.unism.ac.id DOI: https://doi.org/10.33859/dksm.v10i2

Pengaruh Kualitas Pelayanan Terhadap Tingkat Kepuasan Pasien BPJS Di Pelayanan Rawat Jalan RSUD Ratu Zalecha Martapura Tahun 2019

disebabkan oleh persepsi beberapa pasien yang

tidak merasa puas terhadap pelayanan rumah sakit yang masih memandang status sosial pasien yang masih yang membeda-bedakan pasien.

Dengan persamaan regresi $y=1,054+0,423 x$ disimpulkan semakin baik empati (empaty) maka semakin tinggi tingkat kepuasan pasien BPJS di Pelayanan Rawat Jalan Rumah Sakit Umum Ratu Zalecha Tahun 2019. Semakin baik persepsi pasien terhadap empati (empaty) maka kepuasan pasien akan semakin tinggi, jika persepsi pasien terhadap empati (empaty) tidak baik, maka kepuasan pasien akan semakin rendah.

\section{UCAPAN TERIMAKASIH}

Saya sangat berterimakasih kepada Direktur Rumah Sakit Umum Ratu Zalecha Martapura yang telah memberikan izin untuk melakukan penelitian.

\section{DAFTAR PUSTAKA}

Azwar S. 2013. Sikap Manusia: Teori dan Pengukurannya. Yogyakarta: Pustaka Pelajar.

Alamsyah, D. 2011. Manajemen Pelayanan Kesehatan. Nuha Medika; Yogyakarta.

BPJS. 2018. User Manual Vclaim. Jakarta: Badan Penyelenggara Jaminan Sosial BPJS.

Data laporan Rumah Sakit Umum Ratu Zalecha Martapura tahun 2018.han et al. 2016.

Shan et al. 2016. Patient Satisfaction with Hospital Inpatient Care: Effects of Trust , Medical Insurance and Perceived Quality of Care, 1-19. di akses 05 April 2019

Semiaji, S. 2012. Analisis Pengaruh Kualitas Pelayanan Terhadap Kepuasan Pasien Rawat Inap kelas III Pada RS. Roemani Muhammadiyah Semarang. Fakultas Ekonomi Universitas Diponegoro Semarang. di akses 28 Mei 2019

Sri Siswati. 2015. Kualitas Pelayanan Kesehatan Dengan Kepuasan Pasien Bpjs Di Unit Rawat Inap RSUD Kota Makassar. Bagian Administrasi dan Kebijakan Kesehatan FKM Universitas Hasanuddin. di akses 05 April 2019.

Siti Nurhaida. 2015. Hubungan Kualitas Pelayanan Dengan Kepuasan Pasien Rawat Inap Di RSUD Ampana Kabupaten Tojo Una-Una. Bagian Administarsi dan Kebijakan Kesehatan, Fakultas Kesehatan Masyarakat, Universitas Muhamadiah Palu. di Akses 10 April 2019.

Wijono D. 2009. Manajemen Mutu Pelayanan Kesehatan. Surabaya: Airlangga University Press 